\title{
Strategic coercion and international mediation of atrocity-related conflict
}

\author{
Obinna F. Ifediora \\ School of Political Science and International Studies \\ The University of Queensland \\ obinna.ifediora@uq.edu.au
}

May 2021

\begin{abstract}
This article explains the role of coercion in international mediation of violent conflict involving atrocity crimes from the parties' perspectives. It draws on coercion theory and expands the framework of atrocity mediation, examining the successful yet controversial African Union mediation with the global community in Kenya. Coercion theory aims to solve what this study reads as the agent-coercion problem in the international system: agents retain choice despite coercion by more powerful actors. The framework argues that conflict parties are rational, legitimate voluntary agents who always have choices when considering the cost/benefit consequences of peace initiatives, comprising 1) consenting to mediation, 2) breaking stalemates, or 3 ) reaching compromises while being coerced. Thus, strategy requires mediators to create ripeness by incorporating enticing opportunities in mediation or settlement proposals, accommodating the disputants' core interests. Then coercion's role would be to build consensus on peace offers, persuading reluctant parties that compromise is the better choice than resistance. Importantly, coercion infuses a sense of urgency in the parties' contemplation of the cost/benefit implications of their choices, accelerating decision-making on resolving the proximate causes of violence that triggered atrocities. The study contributes to understanding better the limits of power mediation in international relations.
\end{abstract}

Keywords: coercion, strategy, international mediation, genocide, atrocities, African Union

Acknowledgement: I would thank Chester Crocker for the extremely helpful comments on earlier draft of this paper. All remaining errors are mine. 


\section{Introduction}

This article explains the role of coercion in international mediation of violent conflict situations involving atrocities, such as ethnic cleansing and crimes against humanity, from the parties' perspective. It analyses the successful yet controversial African Union (AU) mediation with the global community in Kenya in 2008. Unlike pure mediation, coercion is a feature of power mediation in international relations. ${ }^{1}$ In violent conflict conditions, the assumption is that coercion could stimulate hurting stalemate, ${ }^{2}$ a vital component of William Zartman's model of ripeness theory. The hurting stalemate paradigm states that conflict parties consent to mediation or settlement proposals after prolonged fighting when the only way out is to avoid further costs and loss of lives. ${ }^{3}$ The idea is that coercing powers could expedite hurting stalemate by providing diplomatic and military support to the weaker party to create a balance of capability and a perception of futility of a military victory by one party, forcing a negotiated settlement.

Moreover, studies underlining the parties' agency and choice point to significant limitations to the hurting stalemate formulation. In particular, Jacob Bercovitch and Richard Jackson stress that 'actors retain ... the freedom to accept or reject mediation or mediators' proposals ${ }^{4}$ despite being coerced. The situation in Syria is illustrative. External powers recognized the opposition Syrian National Council (SNC) as the legitimate government and assisted the Free Syrian Army in its effort to coerce President Bashir al-Assad's resignation. To the SNC and its influential supporters, al-Assad lost legitimacy after state security forces committed atrocities against civilians demanding democratic reforms. The UN-proposed agreement created a pathway for al-Assad's exit, ${ }^{5}$ who resisted and turned to Russia for

\footnotetext{
${ }^{1}$ Touval, Saadia, 'The superpowers as mediators,' in Jacob Bercovitch and Jeffery Rubin, eds., Mediation in International Relations: Multiple Approaches to Conflict Management (London: Palgrave Macmillan, 1992), pp. 232-248; Kleiboer, Marieke, 'Great power mediation: Using leverage to make peace,' in Bercovitch, Jacob, ed., Studies in International Mediation: Essays in Honor of Jeffrey Z. Rubin (New York: Palgrave Macmillan, 2002), pp. 127-140.

${ }^{2}$ Zartman, I. William, and Álvaro de Soto, Timing Mediation Initiatives (Washington, DC: United States Institute of Peace, 2010) pp. 35-42; Greig, J. Michael, and Paul F. Diehl, International Mediation (Cambridge: Polity Press, 2012), p. 181.

${ }^{3}$ Zartman, I. William, Ripe for Resolution: Conflict and Intervention in Africa (Oxford: Oxford University Press, for the Council on Foreign Relations, 1985); Zartman, I. William, 'The timing of peace initiatives: Hurting stalemates and ripe moments,' The Global Review of Ethnopolitics 1:1 (2001), pp. 8-18.

${ }^{4}$ Bercovitch, Jacob, and Richard, Jackson, Conflict Resolution in the Twenty-First Century: Principles, Methods, and Approaches (Ann Arbor: University of Michigan Press, 2009), p. 35. See Ramsbotham, Oliver, Hugh Miall, and Tom Woodhouse, Contemporary Conflict Resolution: The Prevention, Management and Transformation of Deadly Conflicts (Cambridge: Polity, 2011), p 32.

${ }^{5}$ Lundgren, Magnus, 'Mediation in Syria: Initiatives, strategies, and obstacles, 2011-2016,' Contemporary Security Policy 37:2 (2016), pp. 273-288; Zartman, William, 'UN Mediation in the Syrian Crisis,' Syria Studies 11:2 (2019), pp. 1-43.
} 
support. The outcome is a stalemate, a decade-old civil war, and atrocities. The point is that the disputants' agency is crucial for coercion effectiveness, which raises the research question: what is the role of coercion in influencing the parties' choice of mediation or settlement offers?

The study of coercion in international mediation employs the conceptual framework of directive strategy, focusing on mediators' resources $^{6}$ and choices relative to conflict dynamics. ${ }^{7}$ Considering that conflict parties can accept or reject mediation or settlement suggestions while being coerced, this article concentrates on their strategic choices to examine why they comply or refuse. It draws on coercion theory as conceived by Thomas Schelling, Alexander George, and particularly Lawrence Freedman, who emphasized scrutinizing effectiveness from targets' perspectives and the potential of applying the theory in peace processes and in enforcing multilateral policies on basic norms. ${ }^{8}$ Coercion theory aims to solve what this article reads as the agent-coercion problem in the international system: state and non-state actors are voluntary agents who have choices in spite of coerced by more powerful players. The solution consists of seemingly two paradoxical actions: making credible threats and seeking compromises.

This article operationalizes coercion theory by expanding the framework of the concept of 'atrocity mediation'9 that integrates atrocity and conflict prevention strategies, involving settling proximate causes of violence that triggered atrocities to prevent escalation. This is an ambitious strategy. As Ted Gurr reflected after studying multiple cases, while 'Incentives and pressures should focus intensively on [violent] conflict situations,' ultimately 'Only [military] force will work. ${ }^{10}$ Gurr's thought highlights the challenge of coercing free actors, underscoring

\footnotetext{
6 Zartman, I. William, and Saadia Touval, 'International mediation: Conflict resolution and power politics,' Journal of Social Issues 41:2 (1985), pp. 27-45; Bercovitch, Jacob, and Richard Wells, 'Evaluating mediation strategies: A theoretical and empirical analysis,' Peace \& Change 18:1 (1993), pp. 3-25; Beardsley, Kyle C., David M. Quinn, Bidisha Biswas, and Jonathan Wilkenfeld, 'Mediation style and crisis outcomes,' Journal of Conflict Resolution 50:1 (2006), pp. 58-86.

7 Carnevale, Peter JD., 'Strategic choice in mediation,' Negotiation Journal 2:1 (1986), pp. 41-56; Bercovitch, Jacob, 'A case study of mediation as a method of international conflict resolution: The Camp David experience,' Review of International Studies 12:1 (1986), pp. 43-65; Touval, Saadia, 'Mediation and foreign policy,' International Studies Review 5:4 (2003), pp. 91-95.

${ }^{8}$ Schelling, Thomas C., Arms and Influence (New Haven: Yale University Press, 1966); George, Alexander L., 'Theory and practice,' in Alexander George and William E. Simons, eds., The Limits of Coercive Diplomacy (Boulder, CO: Westview Press, 1994), pp. 13-21; Lawrence Freedman, ed., Strategic Coercion: Concepts and Cases (Oxford: Oxford University Press, 1998), pp. 2, 35.

${ }^{9}$ Ifediora, Obinna F., 'Formulative strategy: Why the African Union-led international mediation in South Sudan failed to prevent atrocity crimes,' International Studies Perspectives [forthcoming] (2020), https://doi.org/10.1093/isp/ekaa019> The main text is Babbitt, Eileen F., 'Mediation and the prevention of mass atrocities,' in Serrano Mónica and Thomas G. Weiss, eds., The International Politics of Human Rights: Rallying to the R2P Cause? (Oxon: Routledge, 2014), pp. 55-75.

${ }^{10}$ Gurr, Ted Robert, 'Preventing genocides and mass atrocities: Evidence from conflict analysis,' in Harff, Barbara, and Ted Robert Gurr, eds., Preventing Mass Atrocities: Policies and Practices (Oxon: Routledge, 2018), pp. 60-69, p. 68. See also Harff, Barbara, 'No lessons learned from the Holocaust? Assessing risks of genocide and political mass murder since 1955, American Political Science Review 97:1 (2003), pp. 57-73.
} 
the significance of Kenya's case, especially given the controversy over the role of coercion. The framework utilizes the Carnegie Commission's 'operational prevention' of deadly conflicts and James Waller's 'midstream prevention strategies' for atrocities. Both concepts concern early measures undertaken at the onset of a crisis to settle immediate causes of violence and prevent the escalation of atrocities. The framework adopts Chester Crocker's concept of multiparty mediation to underpin multilateral approaches to conflict and atrocity prevention. ${ }^{11}$

The framework argues that conflict parties are rational, legitimate voluntary agents who always retain choice when considering the cost/benefit consequences of mediation or settlement offers, comprising 1) consenting to mediation, 2) breaking stalemates, or 3) reaching compromises despite being coerced by power mediators. Thus, strategy requires that mediators first create ripeness by accommodating the parties' core interests in mediation or settlement proposals. This strategic imperative makes Chester Crocker's ${ }^{12}$ enticing opportunity model of ripeness theory that emphasizes mediators' role in producing appealing peace offers more relevant than the hurting stalemate paradigm for the framework. In essence, coercing powers must make realistic demands and recommend practical solutions, prioritizing compromise because the outcome of the conflict will always depend on the parties' choices.

After creating ripeness using enticing proposals, then coercion's purpose would be to build consensus on the peace plan, persuading reluctant parties or potential spoilers that the benefits of compliance outweigh the costs of resistance. In other words, coercion seeks to convince hesitant disputants that accepting a bargain is a better choice than the consequences of refusal. Threats that build consensus anticipate future costs, targeting what the belligerents value and would likely lose, not what they already lost. Importantly, coercion infuses a sense of urgency in the parties' consideration of the cost/benefit implications of resistance or acceptance, accelerating decision-making on resolving the proximate causes of violence that triggered atrocities to prevent escalation. Coercive projects must persist and may increase through various stages of mediation once implemented until compromise. The article uses the framework to explain the success of the AU mediation with the UN, the European Union (EU), the US, the UK, and other actors, in Kenya.

\footnotetext{
${ }^{11}$ Carnegie Commission, Preventing Deadly Conflict (New York: Carnegie Corporation, 1997), chapter 3; Waller, James, Confronting Evil: Engaging Our Responsibility to Prevent Genocide (Oxford: Oxford University Press, 2016), chapter 5; Crocker, Chester A., Fen Osler Hampson, and Pamela R. Aall, Herding Cats: Multiparty Mediation in a Complex World (Washington, D.C.: United States Institute of Peace, 1999).

${ }^{12}$ Crocker, Chester A., High Noon in Southern Africa: Making Peace in a Rough Neighborhood (New York: W.W. Norton, 1992). Eileen Babbitt explored the potential application of hurting stalemate in atrocity-related crisis, Babbitt, 'Mediation and the prevention of mass atrocities,' pp. 57-9.
} 
The article's emphasis on the parties' agency contributes to understanding better the role of coercion and the limits of power mediation in international relations, reinforcing the importance of integrating pure and power mediation strategies. ${ }^{13}$ The framework would guide future comparative studies ${ }^{14}$ on why coercion often fails, leading to military force. The article comprises three sections: the theory, the conceptual framework, and the case study components, and progresses in that order.

\section{The Theory of Coercion}

This section discusses the theory of $\operatorname{coercion}^{15}$ to highlight and show solutions to the agentcoercion problem in the international system - the idea that coercion theory is about conquering the challenge of influencing the choices of free agents. ${ }^{16}$ The study of coercion concerns its role in persuading voluntary agents to do or refrain from doing something. Although scholars disagree over the concept's definition, scope, mechanisms, and conditions of success, ${ }^{17}$ they agree on the objective and challenge. Hence, this discussion centres on the common themes to illuminate the agent-coercion problem but leans on David Baldwin's and Lawrence Freedman's approaches to justify its application to international mediation studies.

\footnotetext{
${ }^{13}$ Fisher, Ronald J., and Loraleigh Keashly, 'The potential complementarity of mediation and consultation within a contingency model of third party intervention,' Journal of Peace Research 28:1 (1991), pp. 29-42; Heemsbergen, Luke, and Asaf Siniver, 'New routes to power: towards a typology of power mediation,' Review of International studies 37:3 (2011), pp. 1169-1190.

${ }^{14}$ In line with Babbitt, 'Mediation and the prevention of atrocities,' and Ifediora, Obinna F., International Mediation and the Prevention of Mass Atrocities: Evaluating African Union Mediation in Atrocity Crimes Settings [PhD dissertation], (Brisbane: The University of Queensland, 2019).

${ }^{15}$ Schelling, Arms and Influence; Georg, Alexander L., David K. Hall, and William E. Simons, The Limits of Coercive Diplomacy: Laos, Cuba, Vietnam (Boston: Little Brown, 1971); Young, Oran, 'Strategic interaction and bargaining,' in Oran Young, ed., Bargaining: Formal Theories of Negotiation (Urbana: University of Illinois Press, 1975); Thiess, Wallace J., When Governments Collide: Coercion and Diplomacy in the Vietnam Conflict, 1964-1968 (Berkeley: University of California Press, 1980); George, 'Theory and practice.'; Pape, Robert A., 'Coercion and military strategy: Why denial works and punishment doesn't,' Journal of Strategic Studies 15:4 (1992), pp. 423-475; Freedman, Strategic Coercion; Byman, Daniel, and Matthew Waxman, The Dynamics of Coercion: American Foreign Policy and the Limits of Military Might (Cambridge: Cambridge University Press, 2002).

${ }^{16}$ My thinking about agency is inspired by Rosenau, James N., 'Before cooperation: hegemons, regimes, and habit-driven actors in world politics,' International Organization 40:4 (1986), pp. 849-894; Wendt, Alexander E., 'The agent-structure problem in international relations theory,' International Organization 41:3 (1987), pp. 335370.

${ }^{17}$ For helpful literature reviews, see Bratton, Patrick C., 'When is coercion successful? And why can't we agree on it?' Naval War College Review 58:3 (2005), pp. 99-120; Jakobsen, Peter Viggo, 'Pushing the limits of military coercion theory,' International Studies Perspectives 12:2 (2011), pp. 153-170.
} 
Unlike military force, coercion reflects a preference for diplomacy, what Thomas Schelling called 'the diplomacy of violence,' ${ }^{18}$ in pursuing foreign policy objectives. Coercion is using military power to bargain. Developed in the context of strategic and military studies, David Baldwin's 'Thinking about threats' shows its relevance in international politics, stressing nonmilitary mechanisms. ${ }^{19}$ Equally, Lawrence Freedman's concept of 'Strategic Coercion' advanced the broader outlook, pointing to the changing nature of conflict in the postCold War global system. He argued that

By this time the prototypical conflict no longer appeared as one between great powers for global mastery, but rather the enforcement of policies agreed in multilateral bodies designed to enforce basic norms and principles. $^{20}$

His approach to coercion is crucial for international mediation of atrocity-related conflict. The phrase 'multilateral bodies' underscores actions undertaken through the UN while implementing 'basic norms and principles' refer to human rights, such as the practice of 'ethnic cleansing' of the Serbs in Bosnia and the Kurds in Iraq. Today, the equivalents would be the Rohingyas in Myanmar, the Yazidis in Yemen, and the Tigrayans in Ethiopia. Some of the norms involved comprise the Genocide Convention, the Geneva Conventions, and the Statute of the International Criminal Court (ICC), which deals with preventing and punishing ethnic cleansing, crimes against humanity, genocide, and war crimes. The conclusion is that 'theory must embrace the employment of strategic threats by any politically conscious collectivity for a great variety of potential purposes,' including in 'peace process. ${ }^{21}$ Therefore, the following discussion of primary texts, Thomas Schelling, Alexander George, and Lawrence Freedman, establishes the relevance to international mediation of atrocity-related conflict.

In coercion, the coercing power's objective is to manipulate choices so that the target chooses a particular option. However, the problem of agency makes seeking a compromise an essential component of the strategy, hence 'strategic coercion.' Thomas Schelling's 'diplomacy of violence' stresses that 'the power to hurt [military force] is a bargaining power,' so 'the only

\footnotetext{
${ }^{18}$ Schelling, Arms and Influence, p. 2.

${ }^{19}$ Baldwin, David A., 'Thinking about threats,' Journal of Conflict Resolution 15:1 (1971), pp. 71-78; Baldwin, David, 'The power of positive sanctions,' World Politics 24:1 (1971), pp. 19-38.

${ }^{20}$ Freedman, Strategic Coercion, p. 2. See also Jakobsen, Peter V., Western Use of Coercive Diplomacy after the Cold War: A Challenge for Theory and Practice (London: Macmillan, 1998). On earlier use of the term 'strategic coercion,' see Sullivan, Mark P., The Mechanism for Strategic Coercion: Denial or Second Order Change? (Maxwell AFB, Ala.: Air University Press, 1995).

${ }^{21}$ Freedman, Strategic Coercion, pp. 3, 29, 35.
} 
purpose must be to influence somebody's behavior, to coerce his decision or choices.' He emphasized that 'coercion requires finding a bargain,' what mediation scholars call making a deal, by exploiting the enemy's 'wants and fears.' 22 This means that coercion is about changing the target's thinking by meeting their needs and threatening what they value. As Alexander George put it, there must be 'concessions on behalf of a compromise settlement,' so 'the coercing power may couple its threats of punishment for noncompliance with positive inducements to encourage the adversary to comply with the demand. ${ }^{23}$ The emphasis on coercion and compromise seems contradictory, but it underlines the target's agency and choice, which this article describes as the agent-coercion problem in international politics that the study of coercion seeks to solve.

Lawrence Freedman's treatment of control and coercion illustrates better the agentcoercion problem. Control relates to military victory by 'brute force,' resulting in the seizure of the disputed subject, so the target is deprived of choice. Coercion signifies compromise, as control may not be an 'option' where the target 'cannot [or], should not be defeated because it is a legitimate political entity,' so its 'residual power must be respected and accommodated in an agreement.' Like international mediation involving state and non-state actors, such as rebel groups in Syria and Yemen. In coercion, 'the target retains choice,' because 'voluntary agent has choices and so an option to ignore, deflect, or modify the demands of the coercer as well as acquiesce. ${ }^{24}$ His explanation of agency reflects the philosophical ${ }^{25}$ conversation on coercion. For example, Craig Carr clarified that "coercion is something different from the kind of compulsion that is sufficient to determine events,' given that 'somebody who is coerced into doing something is in charge, in some sense, of what he does or how he acts. ${ }^{26}$ It is this problem of agency that coercion theory addresses. In other words, coercion theory seeks to overcome the challenge of agency and choice.

The insight is that the agent-coercion problem stacks the odds against coercing powers. Thus, in addition to making concessions or seeking compromises, the coercing power's

\footnotetext{
${ }^{22}$ Schelling, Arms and Influence, pp. 2-5. See Art, Jervis A., and Greenhill, Kelly M., 'An analytical overview,' in Greenhill, Kelly M., and Peter Krause, eds., Coercion: The Power to Hurt in International Politics (New York: Oxford University Press, 2017), pp. 3-32.

${ }^{23}$ George, 'Theory and practice,' pp. 16-17.

${ }^{24}$ Freedman, Strategic Coercion, pp. 16, 22-23, 35. See Pape, Robert A., Bombing to Win: Air Power and Coercion in War (Ithaca: Cornell University Press, 1996), p. 13.

${ }^{25}$ Greenspan, Patricia S., 'Behavior control and freedom of action,' The Philosophical Review 87:2 (1978), pp. 225-240; Carr, Craig L., 'Coercion and freedom,' American Philosophical Quarterly 25:1 (1988), pp. 59-67; Anderson, Scott, 'Coercion,' in Zalta, Edward N., ed., Stanford Encyclopaedia of Philosophy (Winter 2017).

${ }^{26}$ Carr, 'Coercion and freedom,' p. 60.
} 
strategy comprises inducing 1) a sense of urgency and 2) the logic of rationality. Alexander George provides a good discussion of both endeavours. Stimulating a sense of urgency involves concerted military, political and diplomatic actions and issuing an ultimatum or deadline. The agent assesses the consequences of resistance and the benefits of compliance within the timeframe. ${ }^{27}$ The aim is to accelerate decision-making, quickening resolution of the proximate cause of the crisis. Inspiring a logic of rationality assumes the opponent is a rational actor who considers information correctly and demands conveyed and risks represented. ${ }^{28}$ However, not all actors are reasonable, so George proposed a behavioural model that accounts for culture, politics, and psychology, what Thomas Schelling described as generating enough 'intelligence' on 'who is in charge on the other side. ${ }^{, 29}$ The point is that the coercer must know the target, illustrating the complexity of the agency factor.

Lawrence Freedman emphasized that the importance of understanding free actors concerns the problematic task of influencing their 'calculations' ${ }^{30}$ of the cost-benefit consequences of complying or resisting. Defiance relates to agents' motivation, so it plays a vital role in determining how much cost they are willing to bear. Indeed, one of the substantial challenges facing the coercing power concerns the value the target attached to the disputed subject. The higher the value, the greater the motivation to defy pressure and incentives, making coercive campaigns even more confronting. Robert Pape's analysis of costs and benefits is helpful. He stresses threats directed at the target's benefit side to neutralize expected gains from embarking on or continuing the action. So, the coercer must increase the benefit of compliance and increase the costs of resistance. ${ }^{31}$

Nevertheless, the agent-coercion problem complicates Robert Pape's solution if the target implements a 'counter-coercion,' 32 involving measures to deflect or offset the impact of

\footnotetext{
${ }^{27}$ George, 'Theory and practice,' p. 17. See Lauren, Paul G., 'Ultimata and coercive diplomacy,' International Studies Quarterly 16:2 (1972), pp. 131-165.

${ }^{28}$ On rational choice theory, see Arrow, Kenneth J., Social Choice and Individual Values (New Haven: Yale University Press, 1951); Arrow, Kenneth J., Rational choice functions and orderings,' Economica 26:102 (1959), pp. 121-127.

${ }^{29}$ George, 'Theory and practice,' p. 13, 15; Schelling, Arms and Influence, p. 175. For application of behavioural approach, see Brooks, Risa A., 'Sanctions and regime type: What works, and when?' Security Studies 11:4 (2002), pp. 1-50.

${ }^{30}$ Freedman, Lawrence, Strategy: A History (New York: Oxford University Press, 2015), p. 13.

${ }^{31}$ Note that Pape's suggestion that threats against 'civilian vulnerabilities' do not work underscores his focus on military targets, Pape, 'Coercion and military strategy,' pp. 437-8. Indeed, Thomas Schelling had observed that 'The preoccupation with vulnerability that began in 1957 or so was not with vulnerability of women and children and their means of livelihood,' Schelling, Arms and Influence, p. 232. In today's conflict settings, the belligerents' exploitation of civilian weaknesses is a motivation for intervention.

${ }^{32}$ Freedman, Strategic Coercion, p. 30; Byman and Waxman, The Dynamics of Coercion, pp. 142-147, 194-198; Byman, Daniel, and Matthew Waxman, 'Defeating US coercion,' Survival 41:2 (1999), pp. 107-120; Harvey,
} 
coercion or raise the coercer's enforcement costs. Lawrence Freedman explains that enforcement costs relate to implementing coercive projects, like damages to reputation and credibility arising from the failure and material expenditure. Counter-coercion represents a variable that forces the coercer to amend demands and seek a compromise, demonstrating that the outcome always depends on the agent's choice. Considering that "a form of 'hurting stalemate' is produced" in counter-coercion, Freedman suggests the solution would be to 'seek a lasting settlement' or compromise. The pertinent implication of enforcement costs is that they require the coercing power to make an apparent and realistic demand ${ }^{33}$ that centres on compromise.

Thomas Schelling provided an exception to the requirement of clarity, what he characterized as the "hard choice between being clear so that [the target] knows what we want or vague so that he does not seem too submissive when he complies.' The relevance of Schelling's exemption is to address the problem of 'irrational' agents, whose concern is appearance than substance. This understanding leads to one of Schelling's most insightful solutions to the agent-coercion problem, that is, 'coercion depends on the threat of what is yet to come than the damage already done. ${ }^{34}$ In other words, to stimulate rationality and a sense of urgency, coercion and compromise may focus on maintaining the status quo, not restoring the status quo ante. For instance, in atrocity mediation, the aim should be to prevent the escalation of atrocity crimes, not accountability.

Finally, a crucial aspect of the theory relates to the concepts of deterrence and compellence. Thomas Schelling described deterrence as the 'latent violence that can influence someone's choices.' He explained that deterrent threats are like 'statics' or structures established to dissuade the target from initiating actions and 'involves setting the stage' that are often 'nonintrusive, nonhostile, nonprovocative' and then waits for the target's reaction. An excellent example of a deterrent mechanism is a no-fly zone, so the outcome depends on whether the agent decides to fly within the restricted space. If the target makes no move, then the coercer needs not to take further action and may wait indefinitely. On the other hand, he portrayed compellent threats as 'dynamics' or measures undertaken to persuade the target to

Frank P., 'Getting NATO's success in Kosovo right: The theory and logic of counter-coercion,' Conflict Management and Peace Science 23:2 (2006), pp. 139-158.

${ }^{33}$ Freedman, Strategic Coercion, pp. 33, 35. See Thiess, When Governments Collide, pp. 386-99.

${ }^{34}$ Schelling, Arms and Influence, p. 172, 175. 
withdraw or stop the action. ${ }^{35}$ An apt illustration of a compellent mechanism is air strikes if the target ignores the no-fly zone. Either way, the threat that induces compliance must be credible but need not be implemented. ${ }^{36}$

\section{The Conceptual Framework of Atrocity Mediation}

This section expands the framework of atrocity mediation ('the framework') to operationalize the coercion theory. The concept of atrocity mediation argues that grave breaches of the Genocide Convention and the Rome or ICC Statute in conflict situations create a 'logic of coercion,' making the directive strategy of conflict mediation that anticipates coercive approaches pertinent. Thus, the concept integrates 1) atrocity prevention measures that emphasis coercive approaches and 2) conflict mediation that underlines compromise. ${ }^{37}$

The framework aims to solve the agent-coercion problem in international mediation of atrocity-related conflict and explain the role of coercion in persuading conflict parties to settle the proximate causes of violence that triggered atrocities. In seeking solutions to the agentcoercion problem, the framework adopts strategies for atrocity and conflict prevention. It draws on Ted Gurr's emphasis on 'incentives and pressure' within James Waller's 'midstream prevention strategies' in crises involving atrocities. It embraces the Carnegie Commission's idea of 'operational prevention' of deadly conflicts. ${ }^{38}$ These concepts underscore measures undertaken at the onset of violent crises to prevent escalation.

The nature of the agent-coercion problem in atrocity-related conflict is that the belligerent parties are legitimate voluntary agents who make rational choices to engage in violence against civilian populations and commit atrocities. The term 'conflict parties' includes state and non-state actors, like political parties and rebel groups, such as those in Yemen, Myanmar, and Ethiopia. The term excludes non-state actors of extremist characters, such as

\footnotetext{
${ }^{35}$ Schelling, Arms and Influence, pp. 5, 71-2. (Emphasis is in the original text.) On the application of compellence, see George, 'Theory and practice,' 7-8; Pape, 'Coercion and military strategy,' pp. 424-5. On the application of deterrence and compellence, see Freedman, Strategic Coercion, pp. 19-20; Byman and Waxman, The Dynamics of Coercion, pp. 7-9.

${ }^{36}$ Freedman, Strategic Coercion, p. 21; Byman and Waxman, The Dynamics of Coercion, p. 3.

${ }^{37}$ Ifediora, 'Formulative strategy.' The main text is Babbitt, 'Mediation and the prevention of mass atrocities.'

${ }^{38}$ Gurr, 'Preventing genocides and mass atrocities,' pp. 61-3; Waller, Confronting Evil, chapter 5; Carnegie Commission, Preventing Deadly Conflict, chapter 3.
} 
the Islamic State (or ISIS) and the Lord's Resistance Army in Northern Uganda for reasons outlined below.

The framework's assumption of 'legitimate voluntary agents' underpins the idea that states and non-state actors are recognized political entities in the international system, ${ }^{39}$ so their claims, status, and power are respected and accommodated. The commission of atrocities by these agents does not delegitimize their position, which explains their continuing representation and recognition at peace talks. Legitimate agency means that mediators cannot take control of disputed subjects, often state power or sovereignty, as they belong to the disputants. Thus, mediation or settlement proposals must address their core interests. Voluntary agency implies the belligerents retain the choice to accept peace initiatives or pursue other routes to victory. As such, coercion must aspire to promote the essence of mediation: facilitating an agreement.

The framework's presumption of rationality is based on studies ${ }^{40}$ showing conflict parties' engagement in organized violence against ethnic or religious groups is just a part of a broader strategy of gaining or acquiring power. Within this framing, perpetrating atrocities is a deliberate choice of or means to security, political or economic autonomy, not an irrational end. So, mediators' peace plans should include opportunities for achieving the objective, coupled with credible threats. This underlines the significance of studying coercion effectiveness from the parties' viewpoint, reinforcing Lawrence Freedman's salient point that 'The study of strategy ... requires examining political affairs from the perspective of those involved without necessarily identifying with their goals. ${ }^{41}$

The framework argues that conflict parties are rational actors who attacked civilian populations after considering the costs and benefits. State and rebel groups' leadership make such strategic analyses before choosing to commit crimes as a means of advancing their objectives. The belligerents' use of strategic violence demonstrates high motivation and selfinterest and should make strategic coercion a more challenging endeavour. Nevertheless, the inherent rationality of the disputants' aspirations provides an opportunity for compromises. The urgency of preventing atrocities requires mediators and coercing powers to undertake early

\footnotetext{
39 Coggins, Bridget, 'Friends in high places: International politics and the emergence of states from secessionism,' International Organization (2011), pp. 433-467; Huang, Reyko, 'Rebel diplomacy in civil war,' International Security 40:4 (2016), pp. 89-126.

${ }^{40}$ Hultman, Lisa, 'Battle losses and rebel violence: Raising the costs for fighting,' Terrorism and Political Violence 19:2 (2007), pp. 205-222; Wood, Reed M., 'Rebel capability and strategic violence against civilians,' Journal of Peace Research 47:5 (2010), pp. 601-614; Valentino, Benjamin A., 'Why we kill: The political science of political violence against civilians,' Annual Review of Political Science 17 (2014), pp. 89-103. ${ }^{41}$ Freedman, Strategic Coercion, p. 15.
} 
active measures to facilitate negotiation or an agreement. Still, the agent-coercion problem means the belligerents retain the choice to reject or accept peace proposals.

In exploring the disputants' choices amidst influence campaigns, the framework considers the assumption that 'coercion cannot be applied in any value-free manner' in violent conflict settings and implements Chester Crocker's enticing opportunity model of the ripeness theory. ${ }^{42}$ The enticing opportunity paradigm stresses mediators' peace initiatives to create ripe moments for negotiation or settlement. The pertinent issue about the parties' choices is why they would abandon their strategy and turn to the negotiating table or reach a compromise. The framework stresses that the belligerents assess the cost-benefit implications of the decision to 1) consent to mediation, 2) break a stalemate, or 3) reach a compromise, depending on the stage of the conflict. So, mediators must offer an enticing opportunity to influence each choice.

\section{Coercion and Consent}

The ripeness theory, sometimes called the readiness theory, guides the study of when and why conflict parties' consent to mediation offers in international mediation. ${ }^{43}$ The concept asks the question of the right time or ripe moment for mediators to intervene. There are various conceptions of ripeness, ${ }^{44}$ but William Zartman's ${ }^{45}$ formulation is widely used. His concept argues that belligerents will probably welcome mediation proposals when they are in a mutually hurting stalemate, and the only option for resolution is a negotiated outcome after prolonged fighting. It is the moment the parties' efforts have failed, so they seek to avoid further costs and loss of lives. The presumption is that coercion could help trigger a deadlock if the coercing power provided diplomatic, political, economic, and military support to the weaker party. However, the agent-coercion problem complicates this proposition, as Syria's example shows.

\footnotetext{
${ }^{42}$ Airaksinen, Timo, 'An analysis of coercion,' Journal of Peace Research 25:3 (1988), 213-227, p. 213; Crocker, High Noon in Southern Africa.

43 Zartman, Ripe for Resolution; Haass, Richard N., 'Ripeness and the settlement of international disputes,' Survival 30:3 (1988), pp. 232-25; Kleiboer, Marieke, 'Ripeness of conflict: A fruitful notion?,' Journal of Peace Research 31:1 (1994), pp. 109-116; Pruitt, Dean G., 'The evolution of readiness theory,' in Galluccio, Mauro, ed., Handbook of International Negotiation: Interpersonal, Intercultural and Diplomatic Perspectives (Heidelberg: Springer, Cham, 2015), pp. 123-138.

${ }^{44}$ Mitchell, Christopher, 'The right moment: Notes on four models of "ripeness",' Global Society 9:2 (1995), pp. 38-52.

${ }^{45}$ Zartman, Ripe for Resolution.
} 
Alternatively, the framework builds on Chester Crocker's enticing opportunity ${ }^{46}$ paradigm of ripeness that stresses making concessions and compromises, proposing solutions with innovative gains, and incentives for embracing peace offers or recommended settlements. In other words, the enticing opportunity model is futuristic, as it concerns values and advantages the parties would likely receive if they complied, pointing to Thomas Schelling's insight that 'Coercion depends more on the threat of what is yet to come than on damage already done. ${ }^{47}$

While the enticing opportunity idea indicates a preference for positive coercion, ${ }^{48}$ it does not exclude negative threats. As Chester Crocker and co-authors have suggested, 'military force' may be necessary to halt 'genocide as a prelude to formal mediation. ${ }^{49}$ The use of force or coercion to stop atrocities is different from obtaining consent to mediation, as the former may not necessarily lead to negotiation, as in Myanmar. In consent, the coercing powers encounter the agent-coercion problem and must convince the parties that negotiation is a better choice. As Kyle Beardsley noted, conflict parties only accept mediation when they expect benefits. ${ }^{50}$ State authorities often reject mediation and negotiation with rebel groups to avoid legitimizing their claim and status. The current crisis in Ethiopia is indicative.

The Ethiopian Prime Minister, Abiy Ahmed, has been resisting mediation offers from the AU, supported by the UN and the EU, relating to the conflict and atrocities in the country's Tigray region. Ahmed's resistance reflects the choice to fight and win. Although succumbing to diplomatic pressure to meet with AU mediators in Addis Ababa on 27 November 2020, he rejected official mediation. Again, he exercised choice to wage war against the deposed regional government, the Tigray People's Liberation Front (TPLF). The international community now faces the challenge of influencing his thinking and choice of mediation, using coercive campaigns. The EU already implemented sanctions, demanding a ceasefire,

\footnotetext{
${ }^{46}$ Crocker, High noon in Southern Africa, pp. 468-82. See Mitchell, 'The right moment,' p. 44; Ohlson, Thomas, 'Understanding causes of war and peace,' European Journal of International Relations 14:1 (2008), pp. 133-160.

${ }^{47}$ Schelling, Arms and Influence, p. 172.

${ }^{48}$ Baldwin, 'The power of positive sanctions,'; Drezner, Daniel W., 'The trouble with carrots: Transaction costs, conflict expectations, and economic inducements,' Security Studies 9:1-2 (1999), pp. 188-218; Lawson, Fred H., 'Using positive sanctions to end international conflicts: Iran and the Arab Gulf countries,' Journal of Peace Research 20:4 (1983), pp. 311-328.

${ }^{49}$ Crocker, Chester A, Olser F. Hampson, and Pamela Aall, 'Why mediation matters: Ending intractable conflicts,' in Jacob Bercovitch, Victor Kremenyuk, and William I. Zartman, eds., The SAGE Handbook of Conflict Resolution (Thousand Oaks: Sage, 2009), pp. 492-505, p. 499. A recent study indicated the importance of coercion for consent in identity-based dispute, Eriksson, Jacob, 'Coercion and third party mediation of identity-based conflict,' Review of International Studies 45:3 (2019), pp. 387-406.

${ }^{50}$ Beardsley, Kyle, 'Why accept mediation?' in Kyle Beardsley, The Mediation Dilemma (Ithaca: Cornell University Press, 2011), pp. 44-71.
} 
humanitarian access, and dialogue, while the US threatened consequences for it characterized as 'ethnic cleansing' and demanded the withdrawal of foreign troops. ${ }^{51}$ Ahmed agreed to withdraw Eritrean troops but not mediation - a sign of initial success.

In strategic coercion terms, the issue here is how to inject a sense of urgency into Abiy Ahmed's calculation and stimulate the choice of consent to mediation. The framework argues that this would involve coercive campaigns to raise the cost of resistance above the cost of compliance, which requires intelligence on the parties' 'wants and fears.' Ahmed's compliance costs - his fears - involve appearing weak to other Ethiopian regional authorities who may be deliberating similar actions as the TPLF. The resistance costs - his wants - include avoiding economic and diplomatic sanctions and investigation, indictment, prosecution, and the possibility of military action. The insight of enticing opportunity is that coercing powers supporting AU mediation proposals must demonstrate gains in compliance and losses in rejection. Enticing opportunity anticipates benefits from the process, so coercion persuades reluctant parties.

\section{Coercion and Stalemate}

The issue here is how to influence the disputants' choice of returning to the negotiating table after a failed attempt. The choice involves consent, albeit at a different stage of the conflict. Studies on stalemate ${ }^{52}$ encompass considerations of what it would take to convince the belligerents to reach an agreement or revisit negotiation, which is the focus here. Roger Fisher and William Ury suggest 'generating a variety of possibilities' as essential factors in persuading the parties to resume negotiation. ${ }^{53}$ In other words, developing new proposals. Besides, other studies emphasize using coercive approaches ${ }^{54}$ to alter 'the parties' perceptions

\footnotetext{
${ }^{51}$ Marks, Simon, 'EU suspends nearly €90M in aid to Ethiopia over internal conflict,' Politico 16 December 2020, https://www.politico.eu/article/eu-commission-suspends-nearly-90-million-euros-in-aid-to-ethiopia-overinternal-conflict/ ; Reuters, 'Ethiopia rejects U.S. allegations of ethnic cleansing in Tigray,' 13 March, 2021, https://www.reuters.com/article/uk-ethiopia-conflict-idUSKBN2B50ES

${ }^{52}$ Pruitt, Dean G., and Rubin, Jeffrey, Social Conflict: Escalation, Stalemate, and Settlement (New York: Random House, 1986); Mooradian, Moorad, and Daniel Druckman, 'Hurting stalemate or mediation? The conflict over Nagorno-Karabakh, 1990-95, 'Journal of Peace Research 36:6 (1999), pp. 709-727; Ghosn, Faten, 'Getting to the table and getting to yes: An analysis of international negotiations,' International Studies Quarterly 54:4 (2010), pp. 1055-1072.

${ }^{53}$ Fisher, Roger, and William L. Ury. Getting to Yes: Negotiating Agreement Without Giving In (Boston: Houghton Mifflin, 1981), pp. 10-11.

${ }^{54}$ Kaufman, Sandra, and George T. Duncan, 'Third party intervention: A theoretical framework,' in Rahim, M. Afzalur, ed., Managing Conflict: An Interdisciplinary Approach (New York: Praeger, 1989), pp. 191-211; Downie, Bryan M., 'When negotiations fail: Causes of breakdown and tactics for breaking the stalemate,' Negotiation Journal 7:2 (1991), pp. 175-186, 184; Zartman and De Soto, Timing Mediation Initiatives, pp. 35-42.
} 
and beliefs about preferences for outcomes and the probabilities regarding the consequences of various courses of action. ${ }^{55}$

The framework underlines enticing opportunity involving offering new promises or accommodating the parties' preferences and coercive measures. The challenge is that mediators effectively ask belligerents to re-engage in an endeavour that already failed to meet their needs, even when the initiative has been reformed to incorporate new mediators. The case of South Sudan is indicative. As violence and atrocities escalated after months of fruitless negotiations and failure to implement a ceasefire agreement mediated by the Intergovernmental Authority on Development (IGAD), East Africa's regional body, the principal parties resisted the UN Security Council's demands to engage in further direct talks. The AU stepped in and transformed IGAD mediation to IGAD-Plus, integrating the Security Council, the EU, and other partners as mediators. IGAD-Plus implemented sanctions but created an enticing opportunity by accommodating President Salva Kiir's request to exclude political parties and civil society organizations at the table. IGAD-Plus recognized only President Kiir's group, Sudan People's Liberation Movement in Government, and the main rebel faction, Sudan People's Liberation Movement in Opposition. ${ }^{56}$ The parties chose to resume talks because mediators and coercing powers made concessions, illustrating the use of strategic coercion to end a deadlock.

\section{Coercion and Compromise}

The disputants' choice of reaching a compromise to settle immediate causes of violence that triggered atrocities is consequential. Indeed, the making, offering, and acceptance of concessions is the guiding principle of international mediation as a third party intervention to help the conflict parties find a mutually acceptable solution. ${ }^{57}$ The fundamental issue surrounding compromise is that peace agreements are hardly perfect and typically require several negotiation rounds, as the parties strive for a more favourable outcome. The agentcoercion problem in this context is illustrated by Jacob Bercovitch's discussion of the

\footnotetext{
55 Downie, 'When negotiation fail,' p. 184. See also, Cohen, Raymond, 'Breaking the deadlock: Guarantees in international mediation,' Cambridge Review of International Affairs 14:2 (2001), pp. 39-52.

${ }^{56}$ For a fuller analysis of the international mediation in South Sudan, see Ifediora, Obinna, F., 'Evaluating the African Union-assisted mediation in South Sudan's civil war and atrocity crimes from 2013 to 2015,' in Ifediora, International Mediation and the Prevention of Atrocities, pp. 100-129.

${ }^{57}$ Bercovitch, 'A case study of mediation as a method of international conflict resolution,'; Conlon, Donald E., Peter Carnevale, and William H. Ross, 'The influence of third party power and suggestions on negotiation: The surface value of a compromise,' Journal of Applied Social Psychology 24:12 (1994), pp. 1084-1113.
} 
belligerents' options, where he noted that the 'Outcome is based on the parties' assessment of costs and benefits associated with their choice of (1) reaching an agreement, (2) continuing negotiation, or (3) abandoning negotiation.' The first option implies that instead of ordering the outcome 'differently on the preference scale of each party, we should look at it as a common denominator [compromise] which can create an optimistic attitude and encourage the parties to continue their efforts to reach better agreements. ${ }^{58}$ In essence, provisions of the proposed settlement must entice the parties toward a deal; otherwise, the disputants may choose either of the two remaining alternatives.

The relevance of the 'common denominator' approach for the framework is that mediators must ensure that the parties' choice is reaching an agreement, mainly because the overarching strategy is to settle immediate causes of violence to prevent escalating atrocities. Thus, mediators must create ripeness by proposing a peace plan with enticing opportunity, agreement with provisions accommodating the parties' shared core needs. Considering that the purpose of strategic coercion is to influence the agent's choices, the first task is to offer realistic solution options to encourage the parties to think more about making a deal. The absence of any inspiring recommendations increases the prospect that the parties choose to continue or abandon negotiation.

In South Sudan, for example, one significant reason coercion failed was that the recommended accord disregarded President Salva Kiir's concerns over sovereignty and security. Equally, the opposition leader, Riek Machar, objected to the suggested security and governance structure. Kiir signed the agreement under Security Council pressure, describing it as a draft and the basis of negotiation. ${ }^{59}$ In effect, the parties chose to continue the negotiation.

The framework contends that mediators must create ripeness by modifying proposed agreements, adapting to the parties' wants. Then coercion persuades unconvinced parties that the compromise is a better choice than the consequences of abandoning the negotiation, especially where some of the disputants' initial intention was not to settle. ${ }^{60}$ Crucially, the goal of coercion would be to raise the sense of urgency, accelerating the parties' calculation of costs

\footnotetext{
${ }^{58}$ Bercovitch, 'A case study of mediation as a method of international conflict resolution,' p. 60-1.

${ }^{59}$ Ifediora, 'Evaluating the African Union-assisted mediation in South Sudan's civil war and atrocity crimes from 2013 to 2015.' In many ways, the agreement was rather a peace plan, which took another three years before the parties reached a compromise. On using a peace plan as strategy for negotiation, see Lehrs, Lior, 'Give peace a plan: Peace plans as diplomatic tools and textual agents in conflict areas,' International Studies Quarterly 65:1 (2021), pp. 238-249.

${ }^{60}$ Richmond, Oliver, 'Devious objectives and the disputants' view of international mediation: A theoretical framework,' Journal of Peace Research 35:6 (1998), pp. 707-722.
} 
and benefits of reaching an agreement. By expediting decision-making on the recommended agreement, strategic coercion contributes to building consensus on the proposed deal. Overall, strategic coercion would have three relevant roles, 1) obtaining consent, or 2) breaking stalemate, or 3) consensus-building, as shown in Figure I below.

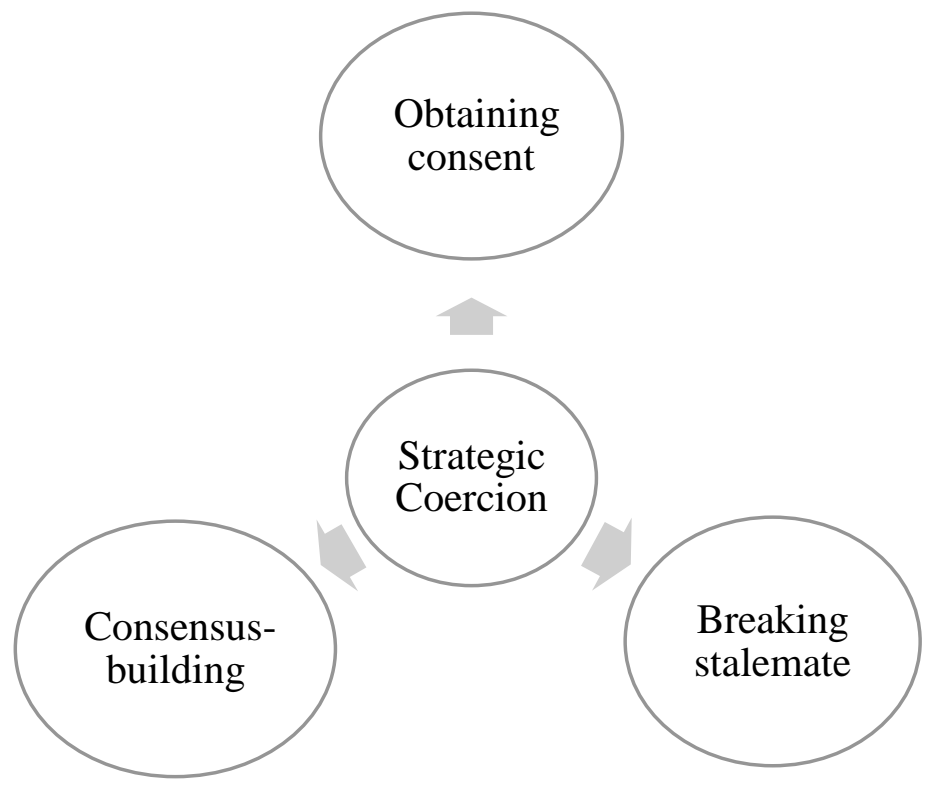

Figure I. The Role of Strategic Coercion

These three roles are not sequential, as initiating coercive campaigns depends on the stage of the conflict atrocities occurred. So, strategic coercion may relevant in the following sequences at various stages of the conflict: consent and consensus-building, breaking a stalemate and consensus-building, and consensus-building, as illustrated in Figure II.

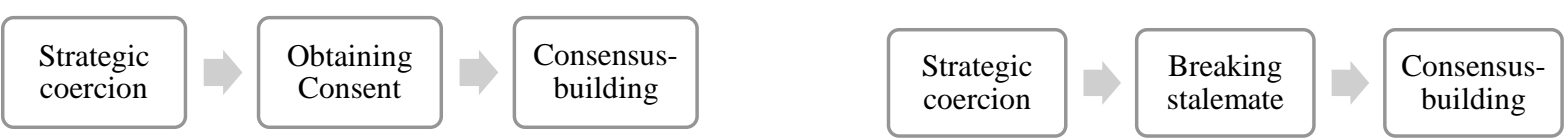

Stage 3

Strategic coercion

Consensusbuilding

Figure II. Stages of Implementing Strategic Coercion 
Once a coercive project commences, it should persist and may require additional measures until compromise (or failure). The logic of sustaining strategic coercion pending an agreement is to maintain a sense of urgency and expedite decision-making on the settlement plan. The three stages are criteria for measuring the success of strategic coercion.

Finally, the framework addresses the conversation on mechanisms of coercion in international mediation. The range of instruments includes sanctions, justice, and military measures - the disagreement centres on the assumption that specific tools are inconsistent with mediation and should not be used. Some scholars consider sanctions and military force, ${ }^{61}$ others accept only sanctions, ${ }^{62}$ while there is a general disinclination toward justice measures ${ }^{63}$ Yet, others caution that 'coercive measures and mediation carried out by the same actor might complicate the success of the latter. ${ }^{64}$

The framework focuses on the objective of coercion, not the nature of the mechanism and who should use it. It stresses that the coercer's identity and the type of instrument are irrelevant for obtaining consent, breaking stalemates, or consensus-building. It embraces the concepts of deterrence and compellence strategy to underpin the broader outlook, conceptualizing the UN Security Council and the ICC as the international community's 'power to hurt,' the collective mechanisms of strategic coercion. While much of the existing literature consider deterrence in the context of preventing future outbreaks of atrocity, ${ }^{65}$ the framework adopts Thomas Schelling's conception of deterrence as 'statics' and compellence as 'dynamics' ${ }^{66}$ and conceives the Security Council and the ICC as structures and measures of strategic coercion.

From a deterrence perspective, the ICC and the Security Council are coercive, dormant structures established to deter or prevent free agents from undertaking actions that may

\footnotetext{
${ }^{61}$ Greig and Diehl, International Mediation, p. 9; Crocker, Hampson, and Aall, 'Why mediation matters', p. 499.

${ }^{62}$ Goertz, Gary, Paul Francis Diehl, and Alexandru Balas, The Puzzle of Peace: The Evolution of Peace in the International System (Oxford: Oxford University Press, 2016), p. 157.

${ }^{63}$ Zartman, I. William, and Mark Anstey, 'The problem: Preventing identity conflicts and genocide,' in Zartman, William, I., Mark Anstey, and Paul Meerts, eds., The Slippery Slope to Genocide: Reducing Identity Conflicts and Preventing Mass Murder (Oxford: Oxford University Press, 2012), pp. 3-24, p.23; Greig and Diehl, International Mediation, pp. 182-3; Goertz, Diehl, and Balas, The Puzzle of Peace, p. 156.

${ }^{64}$ Greig and Diehl, International Mediation, p. 82.

${ }^{65}$ On the ICC, see Kim, Hunjoon, and Kathryn Sikkink, 'Explaining the deterrence effect of human rights prosecutions for transitional countries,' International Studies Quarterly 54:4 (2010), pp. 939-963; Jo, Hyeran, and Beth A. Simmons, 'Can the international criminal court deter atrocity?' International Organization 70:3 (2016), pp. 443-475. On the Security Council, see Russett, Bruce, and James S. Sutterlin, 'The UN in a new world order,' Foreign Affairs 70:2 (1991), pp. 69-83; Hurd, Ian, 'Legitimacy, power, and the symbolic life of the UN Security Council,' Global Governance 8:1 (2002), pp. 35-51.

${ }^{66}$ Schelling, Arms and Influence, pp. 5, 71-2. See also Freedman, Strategic Coercion, p. 20.
} 
undermine international security, including violating basic human rights norms. Their successes mean they would remain inactive indefinitely. However, their deterrence power fails when voluntary agents engage in strategic violence against civilian populations, illustrating the agent-coercion problem and an uncommon type of counter-coercion. From a compellence viewpoint, the ICC and the Security Council are coercive dynamics when they investigate, indict, prosecute, sanction, and use military force to enforce compliance in emerging atrocity situations. ${ }^{67}$ The purpose must be to influence the parties' choices of consenting to mediation, breaking a stalemate, or reaching a compromise, as a strategy of preventing escalating atrocities.

Although the distinction between deterrence and compellence is sometimes unclear in theory and practice, ${ }^{68}$ the framework underlines incidences of atrocities as significant. As Kofi Annan put it:

As important as the council's enforcement [compellent] power is its deterrent power. If states bent on criminal behaviour know that frontiers are not an absolute defence - that the council will take action to halt the gravest crimes against humanity — then they will not embark on such a course assuming they can get away with it. ${ }^{69}$

In essence, deterrence represents the innate inactive power enshrined in the Security Council and the ICC that should influence agents' choices of not committing atrocities. Otherwise, atrocity events demonstrate a choice to violate fundamental human rights precepts, activating compellence. Annan's discussion raises the critical question of why deterrence fails, which some studies have attributed to the lack of credibility. ${ }^{70}$ Lawrence Freedman made the point that 'No matter how sincere the deterrer might be in his conditional threats, if the opponent does not take these threats seriously then deterrence will fail. ${ }^{, 71}$ The framework highlights the idea that the failure of deterrence relates to the parties' consideration of the cost/benefit effects

\footnotetext{
${ }^{67}$ Mendeloff, David, 'Punish or persuade? The compellence logic of International Criminal Court intervention in cases of ongoing civilian violence,' International Studies Review 20:3 (2018), pp. 395-421; Lopez, George A., 'Mobilizing economic sanctions for preventing mass atrocities: From targeting dictators to enablers,' in Rosenberg, Sheri, P., Tibi Galis, and Alex Zucker, eds., Reconstructing Atrocity Prevention, (Cambridge: Cambridge University Press, 2015), pp. 379-92.

${ }^{68}$ Freedman, Strategic Coercion, pp. 19-20; Byman and Waxman, The Dynamics of Coercion, pp. 7-9.

${ }^{69}$ Annan, Kofi, 'Two concepts of sovereignty,' The Economist 352:8137 (1999), pp. 97-8, p. 98.

${ }^{70}$ Weiss, Thomas G., and Karen E. Young,' Compromise and credibility: Security Council reform?,' Security Dialogue 36:2 (2005), pp. 131-154; Glennon, Michael J., 'Why the Security Council failed,' Foreign Affairs 82:3 (2003), pp. 16-35; Roach, Steven C., How political is the ICC? Pressing challenges and the need for diplomatic efficacy,' Global Governance 19:4 (2013), pp. 507-523.

${ }^{71}$ Freedman, Strategic Coercion, p. 24.
} 
of strategic violence before choosing to target civilians. As such, deterrence would almost always fail, making compellence strategy crucial for preventing atrocities.

The framework emphasizes compellence and enticing opportunity, involving modifying demands to accommodate the disputants' primary needs. Compellent threats should seek to encourage the parties to reach an agreement based on future benefits, or as Thomas Schelling stressed, 'Coercion depends more on the threat of what is yet to come than on damage already done. ${ }^{72}$ In Syria, for example, one report ${ }^{73}$ noted that a significant issue with the earlier UN recommended agreement was the expectation that the Syrian government would make most concessions, overlooking President al-Assad's primary interest in power. The injury already inflicted on al-Assad's regime was that external support had weakened the government, stimulating a willingness to share power within an interim arrangement before new elections. Compellent strategy requires practical demands and inspiring offers. For instance, threats of prosecution may concern subsequent crimes, not accountability for crimes already committed. Otherwise, there would be no basis for a bargain.

In sum, the framework conceptualizes compellent campaigns as relating to preventing escalating atrocities, not accountability, which concerns preventing future atrocities. The ICC and the Security Council are the international community's 'power to hurt' and, therefore, 'bargaining power' for influencing the parties' choices of consenting to mediation, breaking a stalemate, or reaching a compromise. The broad mechanisms for compellence involve sanctions, judicial, and military measures ${ }^{74}$ listed in Table I below. The threat or use of these instruments must not alter the purpose of coercion. As rational, legitimate voluntary agents, belligerents always have choices, so the goal is to shape their thinking and decision-making. Success is more likely when mediation or settlement proposals include enticing opportunities that meet their core interests.

\footnotetext{
${ }^{72}$ Schelling, Arms and Influence, p. 172.

${ }^{73}$ Hinnebusch, Raymond, and I. William Zartman, UN Mediation in the Syrian Crisis: From Kofi Annan to Lakhdar Brahimi (New York: International Peace Institute, 2016), p. 1.

${ }^{74}$ On complementarity of tools of strategic coercion, see Thiess, When Governments Collide, pp. 416-20; Byman and Waxman, The Dynamics of Coercion, pp. 33-7; Mueller, Karl, 'Strategies of coercion: Denial, punishment, and the future of air power,' Security Studies 7:3 (1998), pp. 182-228.
} 
Forms

Sanctions (negative or positive)
Justice
Military

Mechanisms

Negative measures: withdrawing diplomatic, economic, financial, trade, and development assistance; an arms embargo

Positive Measures: providing diplomatic, economic, financial, trade, and development assistance

Targeted Measures: travel bans, asset freezes

Investigation, indictment, arrest warrants, prosecution $^{75}$

No-fly zones, precision missile strikes

Lastly, international regimes for protecting human rights norms and principles, such as the Genocide Convention, anticipate that concepts, programs, and efforts designed for implementation should have a multilateral dimension, including global, regional, and national actors. Thus, the framework draws on the concept of multiparty mediation, ${ }^{76}$ which deals with mediation processes undertaken by several actors, like the UN, the EU, the AU, and state parties. Although such mediation initiatives may suffer from coordination problems, they benefit from power mediators, such as the US, Russia, and China. Such initiatives resemble a multiparty power mediation in international relations, as in Syria, South Sudan, and Kenya.

\section{Explaining the Role of Strategic Coercion in Kenya}

This section operationalizes the framework of atrocity mediation to explain the role of strategic coercion in the successful case of Kenya in 2008. The outbreak of violent conflict on 31 December 2007 received tremendous global attention due to fears that the escalating atrocities might lead to a repeat of the Rwandan genocide if not addressed. Also, the crisis posed a credible threat to regional and international security. Kenya is a major regional partner in the global war on terror in East Africa, so preventing the collapse of the country's governance

\footnotetext{
75 The purpose must be to find concessions. On this point, see Miller, Andrew Cesare, 'Plea bargains for peace? The prospects of the International Criminal Court reducing atrocities through negotiated settlements,' MIT Political Science Department Research Paper 2019-20, https://dx.doi.org/10.2139/ssrn.3448707

${ }^{76}$ Crocker, Hampson, and Aall, Herding Cats; Vuković, Siniša, 'Coping with complexity: Analyzing cooperation and coordination in multiparty mediation processes,' International Negotiation 17:2 (2012), pp. 265-293.
} 
institutions was a priority for the international community, particularly the United States. ${ }^{77}$ These two major factors spurred the early AU mediation of the crisis, supported by the UN, the US, and other states.

The proximate cause of the violence that triggered ethnic cleansing and crimes against humanity was a disputed presidential election that led to a power struggle between two main political parties: The Party of National Unity (PNU) and the Orange Democratic Movement (ODM). Kenya's Electoral Commission had declared the incumbent president and leader of the PNU, Mwai Kibaki, the winner of the presidential election conducted on 27 December 2007. Raila Odinga, the head of the opposition party, ODM, accused Kibaki of electoral fraud, while ODM mobilized supporters to protest the result. The demonstration led to a violent confrontation with security services and Kibaki's followers. Ethnic militias aligned with ODM and PNU carried out attacks against civilian populations based mainly on identity and how they voted, resulting in the mass murder of over 1200 people and the displacement of more than 300,000 people.

As President Kibaki resisted mediation offers by eminent Africans, such as Archbishop Desmond Tutu, the US, the UK, and the EU threatened and implemented sanctions. The ICC opened an investigation backed by the UN Security Council. Rwanda requested military force. The intervention prevented the worst outcome, but opinion is divided over the role of coercion. The division can be grouped into three contrasting perspectives. The first group suggests that coercion had no impact in influencing the parties' choices. For example, Elizabeth Lindenmayer and Josie Kaye, who monitored the mediation process from Nairobi, concluded 'that the agreement was [not] the result of coercion from outside forces.' The second group emphasizes economic tools and diplomatic pressure, indicating that the parties' lacked agency. For instance, Jennifer Welsh argued that the peace deal 'was predetermined by the external actors in advance, rather than voluntarily agreed by the parties.' The third group, reflected in the pioneering work of Eileen Babbitt on mediation in atrocity-related conflict situations, shows nuance, stressing the role of sanctions and 'mutual gains,' underscoring the complex interactions between coercion and bargaining. ${ }^{78}$ The point is that we need a better understanding of the role of coercion in facilitating success in a case of such significance.

\footnotetext{
${ }^{77}$ For discussion of the background to the crisis, see Chege, Michael, 'Kenya: back from the brink?,' Journal of Democracy 19:4 (2008), pp. 125-139; Cheeseman, Nic, 'The Kenyan elections of 2007: An introduction,' Journal of Eastern African Studies 2:2 (2008), pp. 166-184.

${ }^{78}$ Lindenmayer, Elisabeth, and Josie L. Kaye, A Choice for Peace? The Story of Forty-One Days of Mediation in Kenya (New York: International Peace Institute, 2009), p. 22; Welsh, Jennifer M., 'Mediation and sanctions:
} 


\section{Methodology}

The study applies the content analysis method to gain a quantitative understanding of the coercive campaigns. Texts comprise mainly primary sources. Kofi Annan's memoir Interventions recounts his interactions with President Kibaki and Raila Odinga. Annan was head of the Panel of Eminent African Personalities (the Panel) mandated by the AU to mediate the crisis. The Panel is the permanent institutional mechanism for mediation and peacemaking in the AU system. Justin Jepson and co-authors' book, Back from the Brink, is a detailed account of the Panel's mediation effort. The authors include members of the Coordination and Liaison Office of the Panel, who witnessed the mediation process and had access to the Panel's confidential reports to the AU. The International Crisis Group's (ICG) Kenya in Crisis report reproduced crucial clauses of the failed World Bank-facilitated agreement. ICG researchers who observed the track two mediation prepared the report. Additional sources involve electronic archives of the UN Security Council, the EU Parliament, the US Senate, and the Office of the Prosecutor of the ICC. Finally, newspaper reports from reputable media.

Stage 1 of strategic coercion in the framework of atrocity mediation, involving obtaining consent and consensus-building, guides the explanation of the successful outcome. The Panel created ripeness using peace offers that accommodated the parties' primary interest in power. The US, the UN Security Council, the ICC threatened prosecution and implemented sanctions. These coercive measures raised the sense of urgency, accelerated decision-making, and built consensus on the proposed compromise.

\section{Strategic Coercion and Obtaining Consent}

The World Bank failed mediation, led by its country director, Colin Bruce, involved ODM and PNU senior officials and business leaders. Although unsuccessful, the initiative's outcome provided the basis for the AU proposals for mediation and compromise. The ICG report noted that while President Kibaki publicly rejected outside intervention, including Archbishop Desmond Tutu's mediation offer, Colin Bruce had mediated more than 'ten rounds of negotiations' between the parties and Kenya's business community, producing the Principles of Agreement. The agreement specified 'that the electoral commission's tallying, compilation and declaration of results was problematic' and recommended 'a "credible, independent and 
impartial [process] which shall not be subject to control by either party, and whose findings and recommendations [the parties] agree to be bound by".' Notably, it proposed 'a panel of eminent Africans' that would oversee 'a 30-day' process 'to make recommendations on the government structure pending a new election.' The suggested compromise for resolving the immediate cause of violence that sparked atrocities was 'a coalition government' based on "mutual agreement. ${ }^{, 79}$ The guarantors included the AU, the US, and the EU. In essence, the parties had discussed and agreed, albeit in principle, that a power-sharing government was the viable political solution to the proximate cause of the crisis. The peace plan was scheduled for parliamentary approval on 10 January 2008.

Pertinently, the peace proposal contained an enticing opportunity: the idea of powersharing appealed to President Kibaki's and Raila Odinga's core interests in power. However, the ICG report observed that the recommendation failed because PNU 'hardliners' persuaded Kibaki to disclaim it just before the signing ceremony. Their concern was that the inquiry clause, establishing 'a panel of eminent Africans,' would likely lead to an adverse outcome the invalidation of Kibaki's election. Thus, while an enticing opportunity existed, the recommendation for an investigation into the election processes unsettled Kibaki and PNU officials, resulting in their choice to reject the compromise. Meanwhile, the AU Chairperson, President John Kufuor, initially mediated the conflict and failed but succeeded in facilitating the AU mediation by modifying the problematic provision to address Kibaki's concern.

Under intense diplomatic pressure, reflected in telephone calls by the US president, George Bush, and the UK prime minister, Gordon Brown, President Kibaki invited President Kufuor to Nairobi for consultation, in line with article 4(j) of the Constitutive Act of the AU. Kufuor first recommended the Principles of Agreement to Kibaki, who dismissed it. However, Kibaki considered Kufuor's suggestion that instead of conducting an inquiry, the 'eminent Africans' could mediate the electoral dispute. ${ }^{80}$ Here, Kibaki's calculation of the cost/benefit implication of accepting a process that would have invalidated his election led to the choice of non-compliance, but the adjustment to the problematic clause opened an opportunity for a benefit, which stimulated compliance. However, Kibaki's ambivalence to AU mediation prompted coercive efforts to obtain consent.

\footnotetext{
${ }^{79}$ International Crisis Group, 'Kenya in crisis,' Africa Report NO. 137, 21 February 2008, pp. 21-22

80 Jepson, Justin, Neha Sanghrajka, Jimmy Ochieng, and Martin Griffiths, Back from the Brink: The 2008 Mediation and Reforms in Kenya (Addis Ababa: Office of the Panel of the Eminent African Personalities, African Union Commission, 2014), p. 21-22; Voice of America, 'AU mediation effort in Kenya ends in failure,' Archive, 27 October, 2009, https://www.voanews.com/archive/au-mediation-effort-kenya-ends-failure
} 
President Kibaki and the PNU saw an advantage in mediation only as a delay tactic to consolidate power. Kibaki's announcement of a coalition cabinet on 11 January 2008, appointing a candidate from the ODM alliance as the vice president, demonstrated the PNU's inclination to strengthen their hold on the executive. The PNU resorted to intimidation, repression, and assassination of ODM politicians. Meanwhile, Raila Odinga and ODM intensified calls for protests as a strategy of exacerbating and sustaining the pressure on Kibaki to concede or accept to share power. ${ }^{81}$ Pertinently, both parties and their agents perceived strategic violence against civilians as a necessary element of their strategy for winning the power struggle, making coercion an essential component of the international community's support to the anticipated AU mediation of the electoral dispute.

Thus, in addition to diplomatic pressure from the US and British governments, the EU took decisive action to obtain consent, implementing sanctions before the arrival of the Panel in Nairobi on 22 January. On 17 January, the European Parliament voted for 'all further budgetary support to the government of Kenya to be frozen until a political solution to the present crisis has been achieved.' ${ }^{82}$ On 19 January, the EU Commissioner for Development and Humanitarian Aid, Louis Mitchel, visited Nairobi to restate EU demands and consequences of noncompliance to President Kibaki. The apparent and realistic demand was that the parties resolve the proximate cause of the violence and atrocities through a negotiated settlement, recognizing and appealing to the disputants' agency and choice. The consequence was the suspension of the much-needed development assistance to Kenya.

Consequently, Kibaki and Odinga expressed commitment to AU mediation through the famous 'handshake' on 26 January. With consent secured, the next challenge for the mediators that required strategic coercion was persuading Kibaki to reach a compromise on the Panel's proposed power-sharing arrangement with Odinga. The potential for escalation of violence and atrocities while negotiation between the PNU and ODM teams continued, albeit slowly and unproductively, resulted in sustaining and introducing additional mechanisms of strategic coercion to raise a sense of urgency in Kibaki's consideration of the cost/benefit of the offer.

\footnotetext{
${ }^{81}$ International Crisis Group, 'Kenya in crisis,' p. 23-24.

82 European Parliament resolution on Kenya, P6TA (2008) 0018, 17 January 2008, para. 18, https://www.europarl.europa.eu/sides/getDoc.do?type=TA\&reference=P6-TA-20080018\&language=EN\&ring=B6-2008-0024
} 


\section{Strategic Coercion and Consensus-building}

The Panel's strategy for preventing the escalation of atrocities revolved around what was known as Agenda 3 of the four Suggested Agenda items for dealing comprehensively with the crisis. Agenda 3 focused on the political conflict, dealing with resolving the electoral dispute, the proximate cause of the violence that triggered atrocities. Crucially, the strategy excluded Agenda 4 relating to accountability. ${ }^{83}$ The plan consisted of 1) creating ripeness with a powersharing proposal that accommodated the parties' core interests in power and 2) leveraging threats of sanction and prosecution implemented by the US, the UN Security Council, the ICC, and others, to build consensus around the coalition government.

During a parliamentary session to brief parliamentarians on the progress of the mediation process on 12 February, Kofi Annan introduced the idea of a coalition government as a solution, ${ }^{84}$ echoing the provision of the failed Principles of Agreement. Like President Kufuor, who suggested the World Bank-brokered peace plan to President Kibaki, AU officials briefed Annan about the agreement. The recommendation created ripeness as it offered an enticing opportunity to the parties - both sides could partake in governing. However, Kibaki and the PNU were unwilling to share executive power with Raila Odinga and the ODM, arguing that Kenya's constitution had no provision for the office of the executive prime minister. Odinga and the ODM were open to an interim government and dismissed any plans that did not include full executive powers. ${ }^{85}$

As negotiations progressed slowly, fears of escalating violence and atrocities prompted further compellent threats to induce compliance. The United States, with the most leverage and power because of its extensive military cooperation with Kenya relating to the war on terror against Al-Shabaab and economic and financial assistance, implemented additional measures. The US threatened to terminate these relationships. In a statement to the Senate Subcommittee on African Affairs hearing on the situation, Jendayi Frazer, the Assistant Secretary of State, Bureau of African Affairs, noted that the State Department had 'made it clear that there will be "no business as usual" with Kenya until there is a real, concerted effort by both the Kenyan Government and its opposition to resolve the issues which generated this tragedy.' The threat of sanctions was credible and clear. The demand to settle the electoral was realistic. Jendayi

\footnotetext{
${ }^{83}$ Jepson et al., Back from the Brink, 'Annex Three: Annotations to the Suggested Agenda,' pp. 253-55.

${ }^{84}$ Lindenmayer and Kaye, 'A choice for peace?' p. 15.

85 Jepson et al., Back from the Brink, 17, 22, chapter two.
} 
Frazer also stated that 'a strong message of accountability' will help prevent escalation of atrocities, ${ }^{86}$ indicating the threat of prosecution.

The threat of prosecution overlapped with the multilateral effort already underway through the ICC and the Security Council. Earlier on 6 February, the UN Security Council had adopted a presidential statement expressing deep concern about the crisis and its regional effects, stressing 'the need to avoid impunity ... and [called] for those responsible for violence to be brought to justice. ${ }^{87}$ More so, the $\mathrm{ICC}^{88}$ had announced a preliminary investigation into the events. Moreover, President Paul Kagame of Rwanda made a unilateral request for military intervention, ${ }^{89}$ as anticipated by article $4(\mathrm{j})$ of the Constitutive Act of the AU, relating to the right of a member state to request intervention. Kagame's appeal reflected his own experience in stopping the Rwandan genocide in 1994 and concern that coercion may be fruitless.

Despite these threats, negotiations on a coalition government continued, illustrating the disputants' agency and choice as they considered the cost/benefit consequences of power distribution. For President Kibaki, the cost was surrendering some aspects of the executive authority to the opposition. At the same time, Raila Odinga perceived cost as being shut out of power, even though he believed in his electoral victory. Importantly, strategic threats against the parties while they bargained on sharing power show the process of consensus-building, as the demand centred on influencing Kibaki's decision-making and choice of reaching a compromise. State parties supporting the AU mediation implemented additional coercive measures to stimulate consensus on interim partnership government, targeting individuals.

Indeed, the initial compellent threats and enforcement measures targeted the Kenyan government, not specific individuals, as the suspension of development assistance and the general threat of prosecution demonstrated. This broad coercive campaign changed and became more focused. According to the ICG report, ${ }^{90}$ the US State Department later sent letters to thirteen Kenyan nationals threatening prosecution, coinciding with Jendayi Frazer's request to the US Senate. The EU, the UK, Canada, Australia, and Switzerland threatened specific

\footnotetext{
${ }^{86}$ The United States Senate, 'The immediate and underlying causes and consequences of Kenya's flawed election,' 7 February 2008, https://www.govinfo.gov/content/pkg/CHRG-110shrg45361/html/CHRG-110shrg45361.htm

${ }^{87}$ United Nations, 'Security Council, deeply concerned about Kenya crisis, its regional impact,' S/PRST/2008/4SC/9242, 6 February 2008.

${ }^{88}$ The International Criminal Court, 'OTP statement in relation to events in Kenya,' 5 February 2008, https://www.legal-tools.org/doc/765584/pdf/

89 Wallis, Williams, 'Kagame urges Kenyan army to act,' Financial Times, 31 January 2008, https://www.ft.com/content/dae796b8-cf7c-11dc-854a-0000779fd2ac

${ }^{90}$ International Crisis Group, 'Kenya in crisis,' p. 28.
} 
sanctions, including travel bans and asset freezes, against named government and opposition officials and their family members. ${ }^{91}$

Still, the agent-coercion problem manifested in President Kibaki's intransigence. Kibaki and the PNU retained choice and refused to comply while being coerced. Although the parties acknowledged the mediators' pressure, describing Kofi Annan as 'the dictator, ${ }^{92}$ they maintained agency, leading frustrated Annan to suspend negotiation between the ODM and PNU teams and turned to Kibaki to seek consensus on sharing power with Raila Odinga.

Kofi Annan's conversation with or rather threats to President Kibaki, which he recorded and reproduced in his memoir, is significant for explaining the role of strategic coercion in building consensus on the proposed coalition government. It demonstrates how Annan articulated the benefits of compliance and costs of resistance, focusing on the future and the importance of threatening the person 'in charge on the other side. ${ }^{93}$ Annan recalled the interaction, thus:

In my meeting with Kibaki, I pressed him, explaining I was in regular contact with key members of the international community. "The international community is picking up that this failure to make a deal is because of the PNU's unwillingness to move. There will be consequences from them if this fails. You're the one in charge here. Save your country. Otherwise you are going to have a lot falling on your head. Mr. President, over one thousand people are dead. It's time to make a deal." 94

Annan's point was that the consequences to Kibaki for not reaching a compromise would be the ICC prosecution, whose prosecutor was already investigating the situation. He invoked the doctrine of command responsibility, which states that those in positions of authority are equally liable to crimes committed by their subordinates if they failed to take reasonable steps to prevent atrocities. As the Head of State and Government, Kibaki was 'in charge' as violence and atrocities unfolded, effectively overseeing ethnic cleansing and crimes against humanity. Kibaki's 'unwillingness to move' created conditions for escalation, making him liable for the

\footnotetext{
${ }^{91}$ Jepson et al., Back from the Brink, pp. 31-32; International Crisis Group, 'Kenya in crisis,' p. 28.

${ }^{92}$ Griffiths, Martin, The Prisoner of Peace: An Interview with Kofi A. Annan (Geneva: Centre for Humanitarian Dialogue, 2008), p. 11.

${ }^{93}$ Schelling, Arms and Influence, p. 175.

${ }^{94}$ Annan, Kofi A., Interventions: A Life in War and Peace (New York: Penguin, 2012), p. 200. (Quotation marks in the original text.)
} 
crimes. The incentive was that if Kibaki compromised, then the command responsibility would not apply, that is, 'Save your country. Otherwise a lot [would be] falling on your head.'

The objective of Annan's threat of prosecution was to build consensus on the proposed coalition government. The threat was credible as it fed off on actions implemented by the Security Council, the United States, and the ICC. Significantly, the threat and demand pointed to Kibaki's responsibility if he rejected the deal, not for past resistance. The crucial request was that Kibaki should 'make a deal,' acknowledging his agency and choice despite being coerced. As a voluntary agent, Kibaki was free to choose between a compromise and prosecution, so strategic coercion focused on influencing his calculation of costs and benefits of either option.

More importantly, by suspending the negotiation and turning to Kibaki, Annan used strategic coercion to accelerate decision-making on reaching a compromise on the proximate cause of violence that triggered and enabled atrocities. The threat raised a sense of urgency, stressing that over 1000 people are dead, so it was time the immediate cause of the violence was resolved to halt further escalation. The purpose of strategic coercion was to persuade reluctant Kibaki that reaching a deal was a better option than noncompliance, that is, consensus-building on the proposed compromise. Eventually, Kibaki chose to compromise and directed his legal advisers to draft the agreement. ${ }^{95}$ The draft was the Agreement on the Principles of Partnership of the Coalition Government, which Kibaki and Odinga signed on 28 February 2008, the same day Annan made the threat and demand.

\section{Conclusion}

Strategic coercion is ambitious, sophisticated, and difficult to implement because of the agentcoercion problem in the international system. The practice has become attractive and common despite its limitations. So, studying and understanding successful cases is crucial for advancing knowledge and reproducing results. This study indicates that failure is more likely because parties are legitimate, rational, self-interested, and motivated. However, the rationale for strategic violence against civilians - to retain or acquire power - provides a balance of success. The framework establishes a solution to the problem, and the analysis shows the probability of success.

\footnotetext{
${ }^{95}$ Jepson et al., Back from the Brink, p. 42; Lindenmayer and Kaye, A Choice for Peace? p. 21.
} 
Now, every conflict situation is unique, so this study does not pretend to specify a comprehensive theory or strategy of coercion in atrocity-related crises. As Alexander George aptly put it, coercion 'is a highly context-dependent strategy,' so any 'abstract model' should be 'a starting point for designing a particular strategy ... for a specific situation. ${ }^{96}$ As such, the framework is a guide for future studies and developing a strategy, albeit on a case-by-case basis. The growing influence of mediation in the international system ${ }^{97}$ and the enduring atrocity character of contemporary conflicts underscore the significance of the framework as a valuable hybrid model for studying modern peacemaking initiatives and cultivating effective strategies.

Broadly, the study raises three substantive conceptual and practical issues in the study of coercion and mediation in international relations. First, the illustration of the agent-coercion problem encapsulates a central feature of global politics, the idea that every actor in the international system is free, justifying examining and understanding events from the parties' objectives and interests. The agent-coercion problem underscores the significance of the disputants' choices, requiring acknowledging and accommodating their status and authority. Strategic violence against civilians is a form of counter-coercion against the international community's deterrent power, the ICC, and the Security Council. Thus, compellent strategy is about accelerating decision-making on suggested peace agreements, not pursuing accountability. ${ }^{98}$ This conclusion does not diminish the importance of accountability, as the case study indicates that credible threats of prosecution are significant but stresses the essence of compellence. Indeed, mediation is not mandatory, ${ }^{99}$ though preferable. Hence, the framework emphasizes strategic coercion when the AU and the international community make the strategic choice of mediation.

Second, the agent-coercion problem highlights the limits of the concept of power mediation in international relations, which remains the best we have for dealing with the realities of today's violent conflicts, involving the parties' strategic choice of breaching fundamental human rights norms. The framework shows that the question is no longer whether

\footnotetext{
${ }^{96}$ George, 'Theory and practice,' pp. 16, 20.

${ }^{97}$ Goertz, Diehl, and Balas, The Puzzle of Peace.

${ }^{98}$ For the debate on the peace versus justice, see Snyder, Jack, and Leslie Vinjamuri, 'Trials and errors: Principle and pragmatism in strategies of international justice,' International Security 28:3 (2003), pp. 5-44; Druckman, Daniel, and Lynn Wagner, 'Justice matters: Peace negotiations, stable agreements, and durable peace,' Journal of Conflict Resolution 63:2 (2019), pp. 287-316.

${ }^{99}$ In Libya, for example, the UN Security Council ignored AU mediation, see De Waal, Alex, 'African roles in the Libyan conflict of 2011,' International Affairs 89:2 (2013), pp. 365-379.
} 
coercion is acceptable or which mechanisms are appropriate in contemporary mediation but about factors that make success more likely. It underlines a vital variable in power mediation: conflict parties are rational actors who make strategic choices to maximize favourable outcomes in the bargaining process of mediation. So, effective coercion strategy must identify, address, and manipulate their 'wants and fears.'

Lastly, the study indicates the potential for international cooperation in the context of integrating pure and power mediation strategies. It reveals opportunities for strategic dynamism in today's complex world, featuring multiple actors of varying degrees of power. As Obinna Ifediora pointed out, the AU provides legitimacy and sovereignty safeguards to member states, implements 'strategic patience' and facilitates early consent. At the same time, external actors, like the US, the EU, and the UN, bring resources and coercive advantage. Each actor's strategic choice is indispensable in forging successful outcomes. The AU's agency and legitimacy rest on policies and strategies, not capacities, for promoting peace and security on the continent. ${ }^{100}$ Thus, as Pamela Aall and Chester Crocker suggested, the AU's mediation efforts 'would produce greater results if linked more directly to tangible sources of leverage, ${ }^{101}$ that is, power mediators. The challenge for cooperation is reconciling the AU's strategic patience with strategic coercion.

\footnotetext{
${ }^{100}$ Ifediora, 'Formulative strategy,'; Hettne, Björn, 'Regionalism and world order,' in Farrell, Mary, Björn Hettne, Luk van. Langenhove, eds., Global Politics of Regionalism: Theory and Practice (London: Pluto Press, 2005), pp. 269-286.

101 Aall, Pamela, and Crocker, Chester, eds., Minding the Gap: African Conflict Management in a Time of Change (Waterloo: Centre for International Governance Innovation, 2016), p. 316.
} 